\title{
From the Perspective of Game Theory, a Unified Market of Construction Land is Constructed
}

\author{
Zhou Haiyan \\ Fuzhou University of International Studies and Trade \\ 350202
}

\begin{abstract}
The 19th Party Congress report clearly deepened the target of promoting urban-rural integration. Establishing a unified urban and rural construction land market is highly significant to break the urban-rural dual structure and balance urban and rural development. Based on game theory, this article made a comparative analysis among the earnings of the rural collective organizations, land enterprises and local governments under the existing land expropriation mode and unified market. We demonstrated that establishing a unified urban and rural construction land market is the optimal choice for interests of the three parties. It is the core point to reducing transaction cost among enterprises, government and rural collective.
\end{abstract}

Keywords-Urban-rural integration; Construction land market

\section{INTRODUCTION}

Since the 90's of the last century, the rapid development of urbanization and industrialization not only drove a new round of economic development in our country, but also increased the demand for land resources. This demand could not be met only by improving the utilization efficiency of the original urban construction land, and a large number of rural land should be converted into construction land. The current law stipulates that the transformation of rural collective land into urban construction land can be realized only through land expropriation by the government. However, under the banner of "public interest", local governments got land from farmers at low prices and sold it to enterprise at high prices, from which they got a huge amount of price scissors. This practice of raising the level of industrialization and urbanization at the cost of sacrificing farmers' interests in land and property was liable to cause sharp and intense social conflicts. At the same time, under the background of rising levels of industrialization and urbanization, farmers had increasingly strong consciousness of land rights because of a significant increase in intrinsic value of rural land. Invisible market of the rural collective construction land can be seen everywhere. In the hidden market, the rights of owners and users of rural collective construction land cannot be guaranteed by relevant laws and regulations, and the collective construction land market needs to be standardized [1].

\section{THE GUIDING IDEOLOGY OF CONSTRUCTING A UNIFIED CONSTRUCTION LAND MARKET BETWEEN URBAN AND RURAL AREAS}

2018 was a year that implemented the great spirit of the nineteen of communist party comprehensively, and laid a solid foundation for building moderately prosperous society in an all-round way. In order to achieve the goal of building a moderately well-off society in an all-round way and deepening the reform, the 19th National Congress of the Communist Party of China continues to carry out implement Urban and Rural Planning Law of the People's Republic of China. Urban-rural integration is the key to achieve urban and rural sustainable development, and advance the path of socialism with Chinese characteristics. It is of great significance to promote urban and rural planning, achieve the integration of infrastructure and public services, improve the mechanism of the system of the integration of urban and rural development, implement the exchange of production factors equally, and balance public resources allocation between urban and rural areas. [2]

\section{ANALYSIS OF GAME MODEL BASED ON THREE - PARTY INTEREST SUBJECTS}

Because of the spontaneity of the collective construction land circulation, the unordered use of land and the chaos of economic order are caused. At present, there are still some problems in the market of collective construction land, such as unclear property right of land, unreasonable distribution of circulation income, and unordered invisible market [3]. Compared with the gradual improvement of compensate system of state-owned land and the market trading system, the construction of collective land market is still largely stagnant. Therefore, the circulation of collective construction land has gradually become a hot issue in China's land management [4].

This paper discusses the necessity of establishing urban and rural unified construction land from the point of view of land price, namely land value.

The main body who participated in the collective construction land circulation mainly includes, owners of the collective construction land (rural collective organizations), the land user (enterprise) and land managers (the local government who accepted the commission of the central government manage the land in the identity of the agent).

Three dynamic game is a game which main participation body can be observed in the choice of the strategy, and others make corresponding choice according to the choice of former. 
By the game among three parties, we decide to build the final collective construction land in the form of an open legal transactions directly into the market circulation, or continue to be carried out in accordance with the disorderly in private transactions. [5]

\section{A. Assumptions}

1)It is rational for all parties to participate under the established conditions

It is assumed that the maximization of self-utility is the behavioral target of the three participants. First of all, in the period of economic and social transformation, as land managers, local governments participate in the market in the form of a corporate resources configuration. In other words, the governments are in pursuit of a specific economic benefit as the goal in a sense. Secondly, as units which using land, the enterprises are rational economic subjects, which are characterized by pursuing the maximization of its own economic benefits. Finally, as the owner of the land, rural collective organizations are the collection of farmers. Accompanied by the fact that farmers' access to information is more and more open and the awareness of independent rights protection has been continuously strengthened, the decisionmaking behavior of farmers' collective selection become certain rationality [6].

\section{2)The information is complete}

All three participants clearly defined the utility function of behavior space between each other, and had a complete and comprehensive understanding of the characteristics, action rules and utility functions of each party.

\section{B. Modeled Element}

\section{1)Participant}

The participants include local government, rural collective organization and land use enterprises. We call them $i_{1}, i_{2}, i_{3}$ respectively.

\section{2) behavior space}

With the game process between enterprise and the collective land ownership, local government has two options: one is to maintain the original circulation mode, that is to say, only through a formal process, namely the traditional pattern of land expropriation, rural collective construction land can be traded listed when it becomes state-owned land. The other is to innovate the original flow pattern. The government can establish or reform the related system and standardize the management of collective construction land. In this way, there is no need to change the nature of the ownership through land expropriation, namely public circulation method. Collective construction land is able to deal in the market circulation directly. Under the different behavior decisions of local governments, the behavior space of rural collective organizations includes: one is to deal in a private way illegally, and the other is access to the open market trading. Similarly, the choice space of land use enterprise behavior includes: first, it flows in from rural collective organization privately; second, it is access to the open market trading.

\section{3) utility function}

In the game process, as rational homo-economics man, the participants aim to maximize the utility U. $U=\left(U_{1}, U_{2}, U_{3}\right)$ is the utility function combination of each participant, namely the total social utility. The utility $U$ of participants mainly depends on the benefit $\mathrm{R}$ obtained by each participant in the process of collective construction circulation and trading and the $\operatorname{cost} \mathrm{C}$ paid.

According to Marx's theory of land rent price, land price is the capitalization of land rent.

Collective construction land price $(\mathrm{P})=$ absolute rent $(\mathrm{R} 0)$ + differential rent I (R1) + differential rent II (R2) + monopoly rent $(\mathrm{R} 3)$

[Note: Differential rent I are different plots on the amount of capital input, due to different fertile degrees of land or the different location of the excess profit margin. Differential rent II is due to the continuous increase investment on the same plot which has a higher labor productivity and the excess profit.]

\section{Specific game strategies of participants}

1)The open market transaction model under the existing land expropriation mode

Under the current legal system, collective construction land must be expropriated by local governments and transferred to state-owned land firstly, and then dealt in the primary market of land. For the rural collective, the land compensation fee contains the absolute land rent $\mathrm{R}_{0}$ because of the transfer of land use right, as well as the land attachment and the compensation fee for green seedlings. The compensation fee of ground attachments and green crops on the ground which paid for the original land user is according to the fertile degree of the land and the location. The extent of compensation with reference to the land fertile and geographical location, is part of the differential rent I. $U_{1}=R_{0}+\lambda_{1} * R_{1}, \lambda_{1}$ is the share of the rural collective organizations obtain differential rent I.

For local governments, the compensation fee included the gain from the increased land productivity that is benefited by government's construction of infrastructure, called the differential rent II, and part of the differential rent I. $U_{2}=R_{2}+\lambda_{2} * R_{1}, \lambda_{2}$ is the share of the differential rent I for local government.

For land companies can gain monopoly profits, and the rest of the differential rent $\mathrm{I}$, at the same time need to take occurring in the process of acquiring land transaction costs $\mathrm{C}_{\mathrm{t}}$. $U_{3}=R_{3}+\left(1-\lambda_{1}-\lambda_{2}\right) * R_{1}-C_{1}$.

\section{2)The tripartite game of underground market trading}

Due to the current imperfect land expropriation model system, unreasonable distribution of the land income, complicated formalities, high transfer cost and long transfer time, an invisible market for land transactions became into being. At the same time, land expropriation mode is mandatory, which cannot reflect the real intention of both parties and cannot reach pare to optimality. Therefore, under the existing land expropriation model, the invisible market of low land is growing. 
For rural collective, they are able to keep away from government land expropriation, and participate in trade in the underground market directly without the intermediate links. Therefore, the rural collective will be able to get a part of the differential rent II belonged to the government. However, facing the possibility of being investigated and punished, there is a certain risk cost, $U_{1}{ }^{\prime}=R_{0}+\omega\left(R_{1}+R_{2}\right)-\varepsilon C_{r} . \omega$ is the proportion that rural collective organizations get from differential rent I and differential rent II, whose value depends on the size of the bargaining power of the rural collective organizations in underground market. $\varepsilon$ is the probability that an underground transaction will be prosecuted, and $C_{r}$ is the penalty imposed upon it.

In consideration of the tiny share that rural collective organization farmers get from differential rent $I$ in the current land expropriation model, and the fact that the current government's supervision and punishment dynamics is small, therefore, $\varepsilon C_{r}$ is small, and $U_{1}{ }^{\prime}>U_{1}$. It suggests that farmers are more likely to opt for underground markets.

For the local government, when collective organizations participate in the underground market directly, the government cannot participate in the distribution of the benefits from land expropriation. At this time, the government's income mainly comes from the punishment of fines for underground transactions. What's more, the government must pay a certain cost of supervision and law enforcement $C_{s} \cdot U_{2}{ }^{\prime}=2 \varepsilon C_{r}-C_{s}$.In the process of land expropriation, the government expropriated farmers' land at a low price, and then transferred it to land enterprises at a high price by means of bidding, etc. Therefore, a lot of land gains were obtained. However, the lack of supervision and punishment of the underground market results in less revenue from the government's investigation. $U_{2}{ }^{\prime}<U_{2}$.Therefore, the government is more inclined to follow the current land expropriation model, but they will increase supervision and increase fines from illegal circulation.

For land use enterprises, the transaction cost of entering the underground trading market is relatively small and negligible compared with the cost from the land expropriation system. Land companies are also at risk of being punished. $U_{3}{ }^{\prime}=R_{3}+(1-\omega)\left(R_{1}+R_{2}\right)-\varepsilon C_{r}$. Because in the process of land expropriation, the local government obtains the large share of differential rent I, in other words, $\lambda_{2}$ is too big. The land use enterprises don't have access to the original belong to the government of differential rent II. What's worse, in the process of land expropriation, land enterprise pays the comparatively higher the transaction cost. Therefore, that is $\lambda_{1}{ }^{\prime}>\lambda_{1}$, and land use enterprises tend to get the right to get the use right of land through private circulation.

In this case, the total social utility $U=R_{1}+R_{2}+R_{3}-C_{s}$. To sum up, the government will choose to follow the existing land expropriation model. On the contrary, rural collective organizations and land enterprises will choose to transfer land through land transactions at low price. The continuous growth of the invisible market not only affects the normal land market order, but also causes the chaos of collective land property rights, and reduces the area of cultivated land. Therefore, the government should strengthen supervision to avoid the loss of rights and interests in land circulation. At this point, the total social utility will decrease as the $\mathrm{C}_{\mathrm{s}}$ increases, and the optimality of the society is not realized. In this case, this three parties involved will make decisions based on their own interests. The government will establish a unified land transfer market between urban and rural areas in order to reduce land underground transactions.

\section{3)Establish a unified construction land market between} urban and rural areas

By establishing a unified construction land market between urban and rural areas, rural collective construction land can be transferred to the land market without going through the original land expropriation procedures. In this mode, the government is indirectly involved in the land circulation of income distribution, instead of getting a certain amount of economic compensation benefits from establishing the function of market and the market management. At this time, the government benefits in the land price is reflected by collecting related land tax.

From the perspective of the land value, it's necessary to establish a unified urban and rural collective construction land market. There's a demand to improve the proportion that rural collective organizations obtain from differential rent I, namely,

$\lambda_{1}{ }^{\prime}>\lambda_{1}$. And reduce the proportion of local government in differential rent $\mathrm{I}, \lambda_{2}{ }^{\prime}<\lambda_{2}$. Make transfer this part of the proceeds to the rural collective organizations and land enterprises for sharing. In addition, in order to maximize the total social utility, the transaction cost of land use enterprises needs to be reduced.

For the rural collective organizations, $U_{1}{ }^{\prime \prime}=R_{0}+\lambda_{1} * R_{1}$. $\lambda_{1}{ }^{\prime}$ is the share that rural collective organizations get from differential rent $\mathrm{I}$ in open land market. $\lambda_{1}{ }^{\prime}>\lambda_{1}$. The share of land revenue obtained by rural land use organizations in open market transactions is greater than that of land expropriation. Therefore, the probability of underground land transaction is reduced.

For the local government, it indirectly participates in the distribution of land benefits by providing a platform for the establishment of a unified land market and the function of managing the market. It contains the profit from the higher land productivity because of the construction of infrastructure, named, differential rent II, and part of the differential rent I. $U_{2}{ }^{\prime}=R_{2}+\lambda_{2} * R_{1} \cdot \lambda_{2}$ 'is the share of differential rent I for local governments. Government in the open market gets gains less than the benefits of land acquisition mode. However, it keeps within limits the underground trade effectively, less the cost of supervision, gains more than in underground invisible market transactions.

For land companies, they can gain monopoly profits $\mathrm{R}_{3}$, and the rest of the differential rent I. At the same time, they need to burden the transaction costs of land circulation process. $U_{3}{ }^{\prime \prime}=R_{3}+\left(1-\lambda_{1}{ }^{\prime}-\lambda_{2}{ }^{\prime}\right) R_{1}-\mathrm{C}_{\mathrm{t}}{ }^{\prime}$. 
To establish a unified urban and rural land market, it is necessary to make the allocation of land benefit reasonable among the three participation. Lower the transaction costs of land enterprises in the process of land circulation, in order to increase the total utility of the society. The open transfer of collective construction land market can make both parties get utilities higher than those in underground market deals. By contrast, the gain of the government is higher than the utility in underground trade, lower than in land expropriation mode when the invisible market does not exist.

TABLE I THREE-PARTY GAME MODEL OF COLLECTIVE CONSTRUCTION LAND CIRCULATION

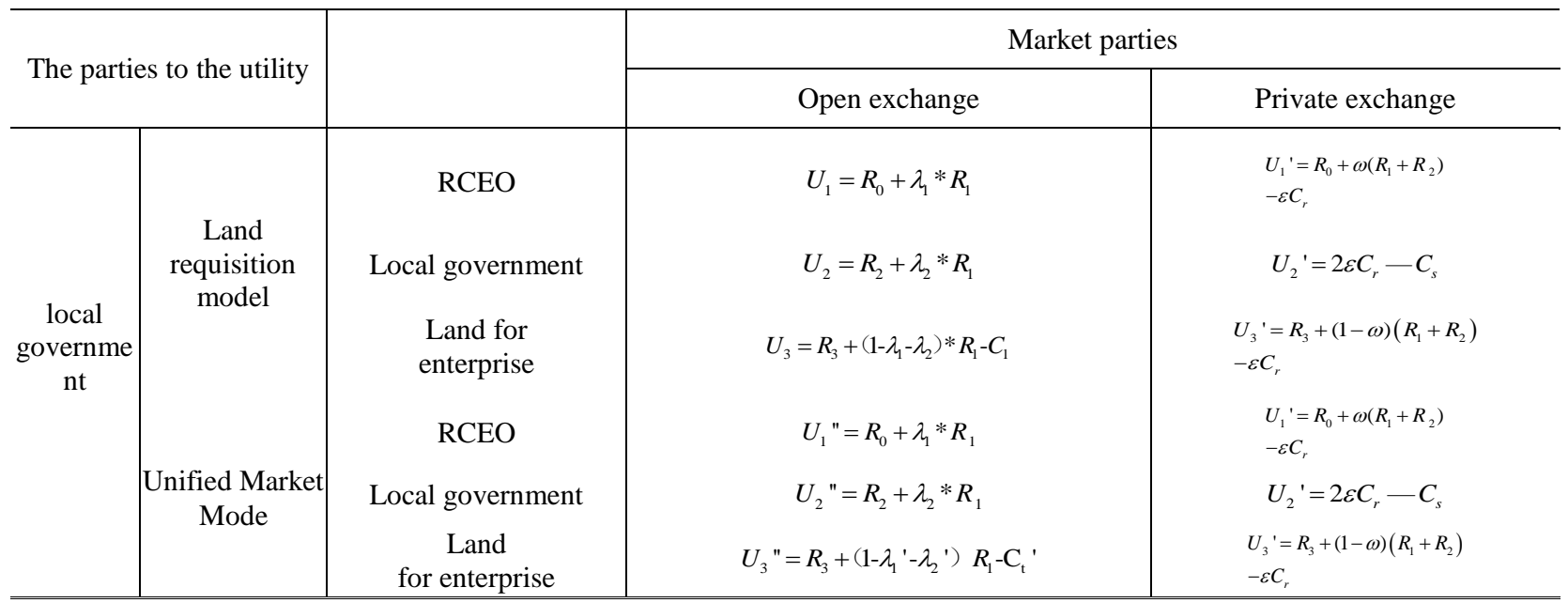

\section{MODEL CONCLUSION}

According to the analysis of game theory above, the conclusion can be drawn:

\section{A. It is imperative to establish a unified construction land market between urban and rural areas}

The establishment the open market of rural collective construction land circulation, and regulating the circulation of collective construction land, which can realize the reasonable distribution of the land income, protect the due rights and interests of farmers, and improve the efficiency of enterprise to obtain land. We need to reduce the hidden market and standardize land market transactions.

\section{B. Lower transaction costs are central}

In order to achieve total social utility, we should accelerate the establishment of a unified urban and rural construction land market, reduce transaction costs among enterprises, government and peasant collective land ownership, including search cost and the cost of rent-seeking cost negotiations.

\section{REFERENCES}

[1] Dai ShuangXing and Li Jianjian. Building a Unified Construction Land Market between Urban and Rural Areas: Premise, Steps and Guarantee [J]. Research on Socialism with Chinese Characteristics,2014,(05):59-63.

[2] Dai WeiGuan. Research on Rural Land Transfer in Urbanization [D]. Shanghai Academy of Social Sciences,2010.

[3] Qi Laiqing and Shi Qiang. Research on Establishing a Unified Construction Land Market in Urban and Rural Areas -- Based on the Investigation and Analysis of Jilin Province's Current Situation [J]. Journal of Northeast Normal University (Philosophy Social Science Version),2016(05):112-116.

[4] Li Yongle, Shu Bangrong and Shi Xiaoping. Urban and Rural Construction Land Market: Segmentation Effect, Integration Key and Unified Path [J]. Journal of Nanjing Agricultural University (Philosophy Social Science Version),2017,17(03):103-111.

[5] Ni Yongjie. Analysis of the Game between the Beneficiaries of the Direct Entry of Collective Construction Land into the Market [J]. Economy and Management,2012,26(05):29-33.

[6] Wang Huan and Yang Xuecheng. Analysis on the Game between Rural Collective Economic Organization and Government in the Market of Urban and Rural Unified Construction Land [J]. Scientific DecisionMaking,2015,(07):37-49. 